\title{
The Yemen War Online: Propagation of Censored Content on Twitter
}

\section{Citation}

Noman, Helmi, Robert Faris, and John Kelly. 2018. The Yemen War Online: Propagation of Censored Content on Twitter. Berkman Klein Center for Internet \& Society Research Publication.

\section{Permanent link}

http://nrs.harvard.edu/urn-3:HUL.InstRepos:34878067

\section{Terms of Use}

This article was downloaded from Harvard University's DASH repository, and is made available under the terms and conditions applicable to Other Posted Material, as set forth at http:// nrs.harvard.edu/urn-3:HUL.InstRepos:dash.current.terms-of-use\#LAA

\section{Share Your Story}

The Harvard community has made this article openly available.

Please share how this access benefits you. Submit a story.

\section{Accessibility}




\section{$\therefore \quad \cdots$}

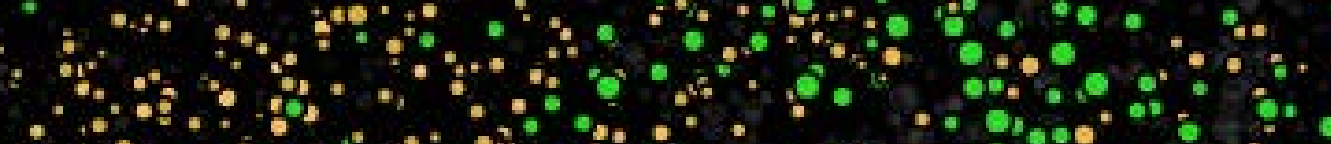

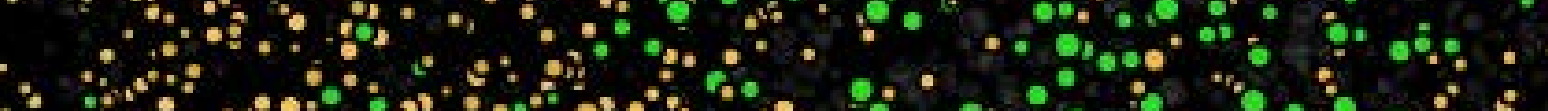

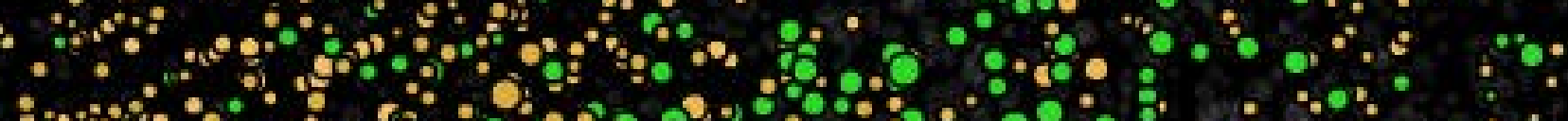

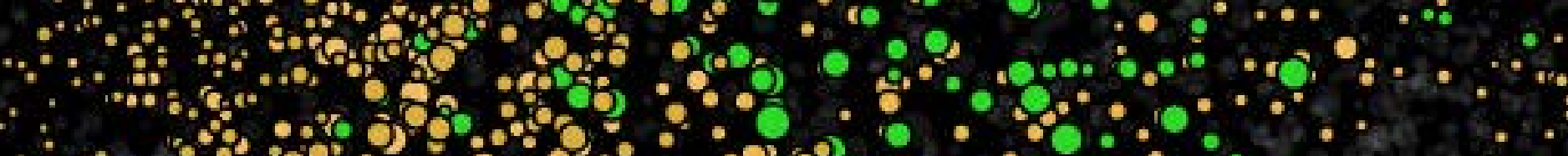

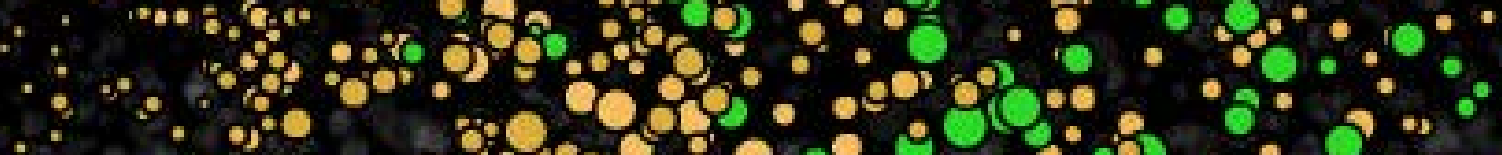

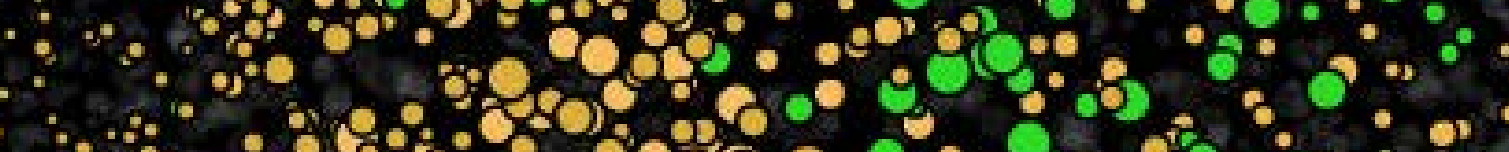

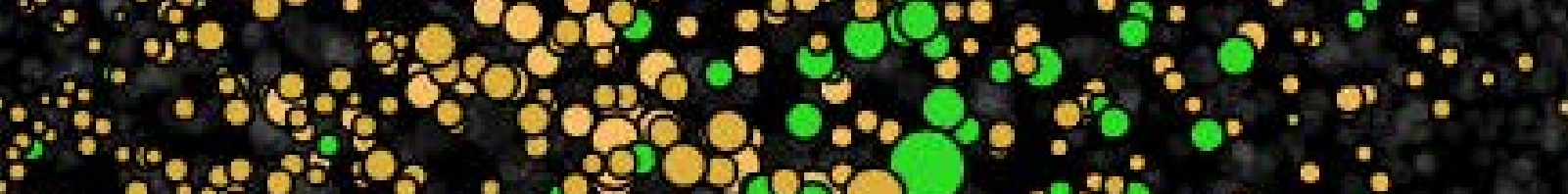

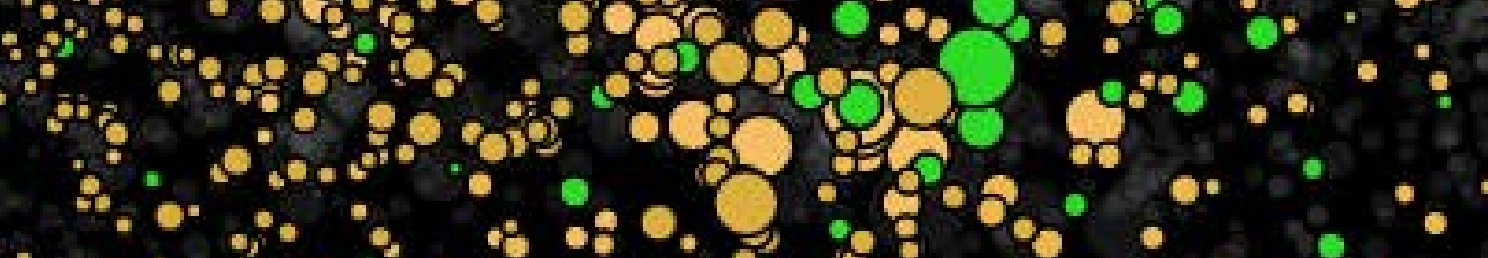

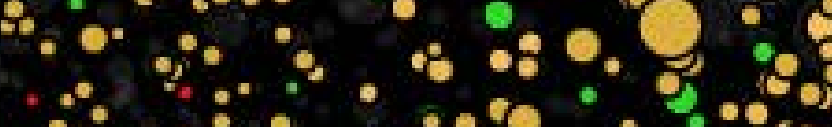

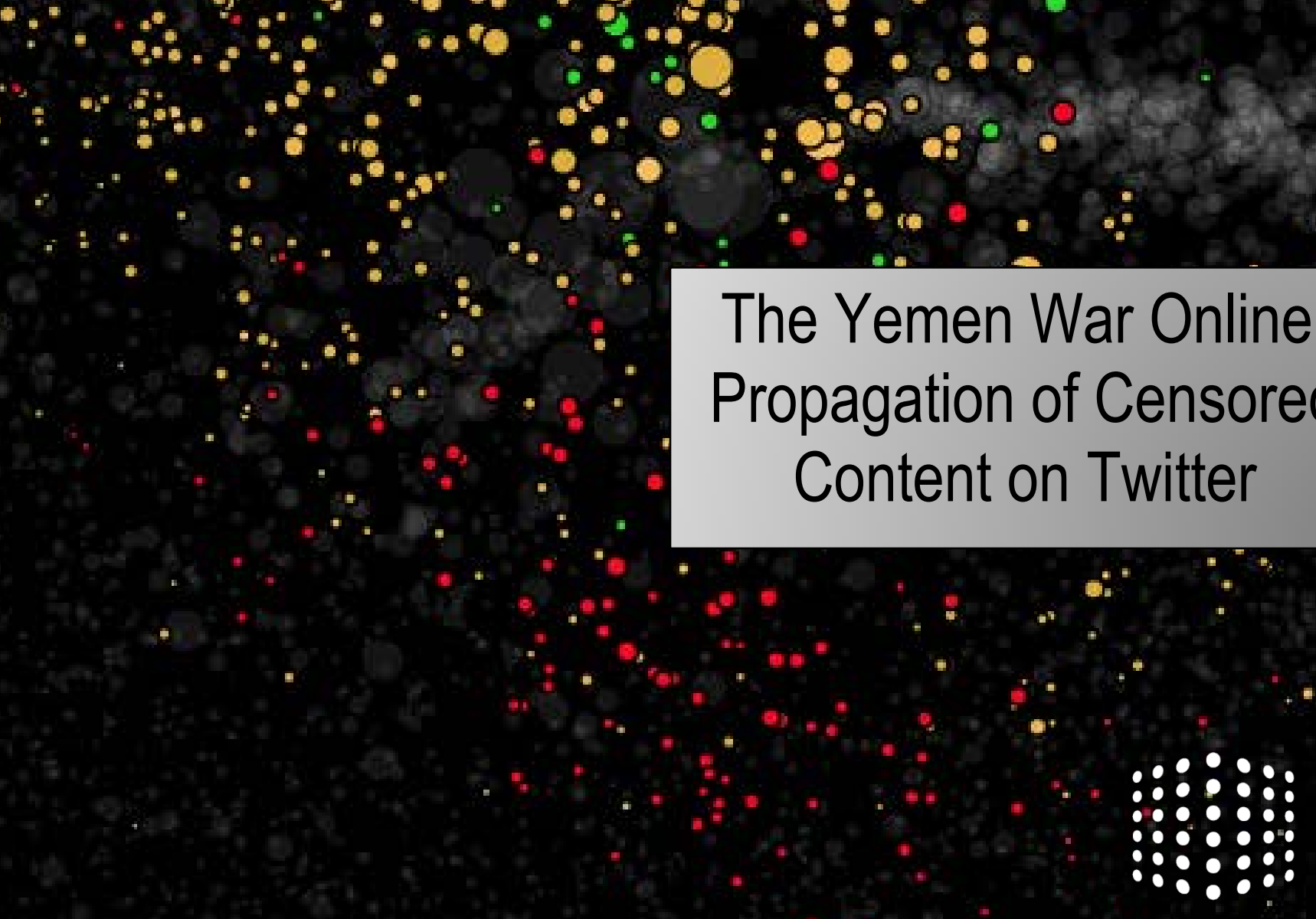

$Q_{0} \cdot 0^{\circ} \cdot$

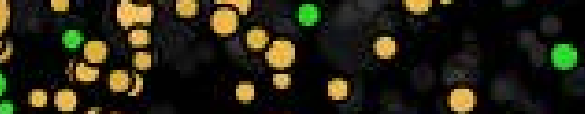
- 80.8.

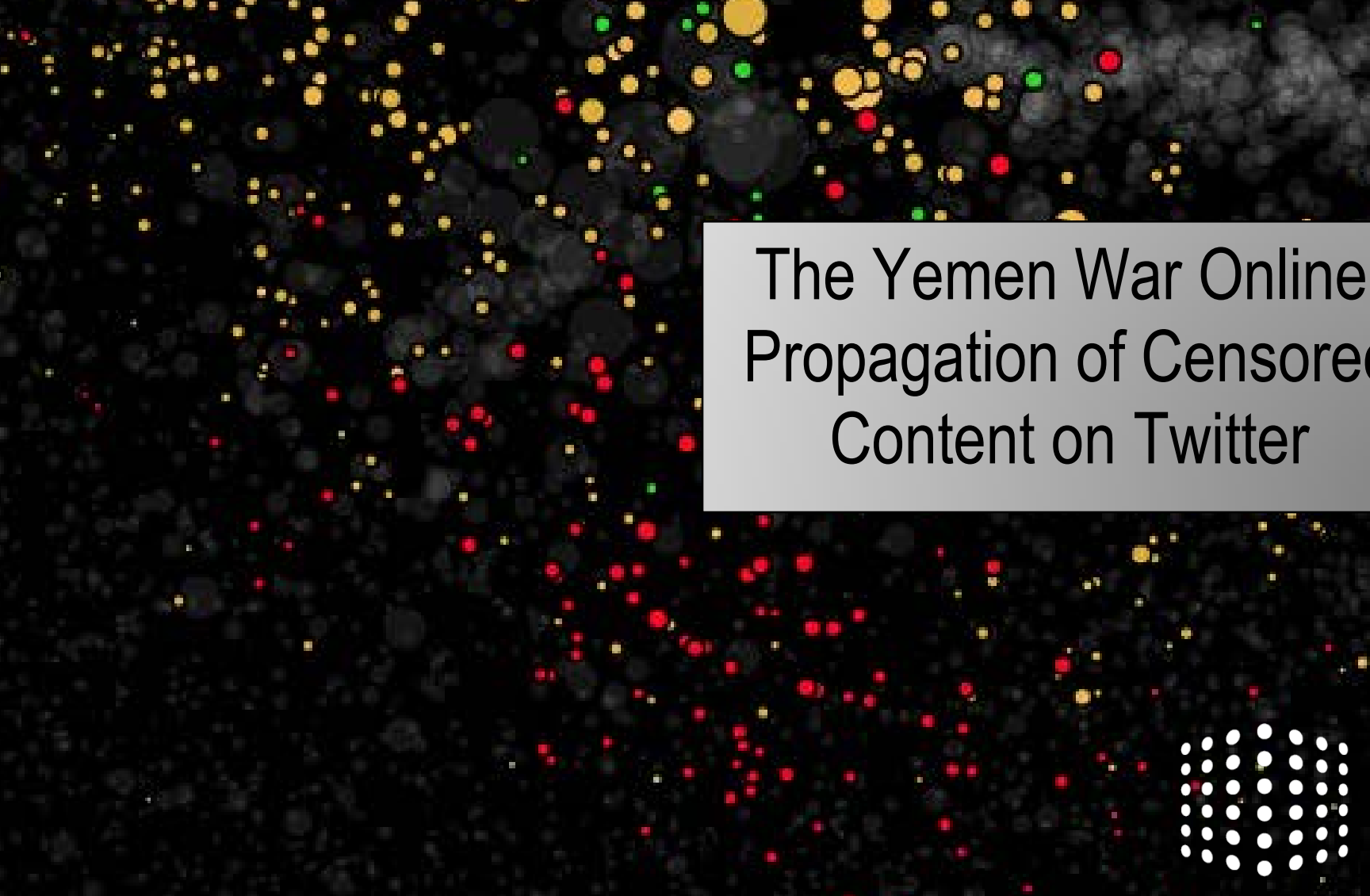


INTERNET MONITOR is a research project to evaluate, describe, and summarize the means, mechanisms, and extent of Internet content controls and Internet activity around the world.

\section{thenetmonitor.org}

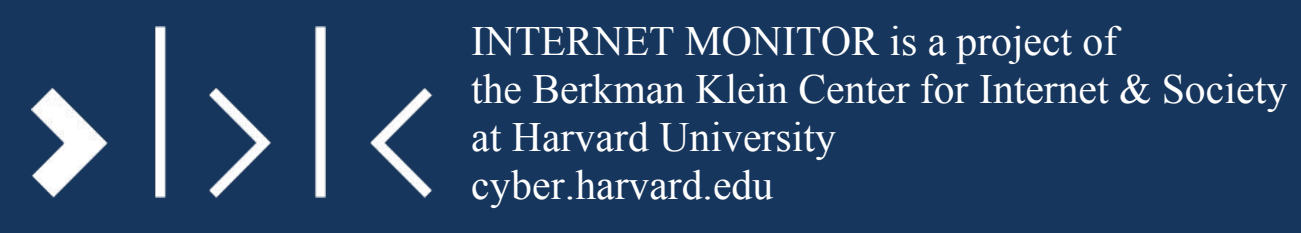

23 Everett Street • Second Floor • Cambridge, Massachusetts 02138

+1 617.495.7547•+1 617.495.7641 (fax)•http://cyber.harvard.edu•hello@cyber.harvard.edu 
February 2018

The Yemen War Online
Propagation of Censored Content on Twitter

Helmi Noman

Robert Faris

John Kelly 


\section{ABSTRACT}

We study the sharing of information on Twitter among different political groups related to the ongoing conflict in Yemen. We find that the networks on Twitter are organized around and segregate along political lines, and cite web content, including censored websites, that reflects and informs their collective framing of the politically sensitive issues. Each of the factions relies almost entirely on their own sources of information. We also test for the availability of this open web content shared on Twitter in the countries most engaged in the public debate over the conflict and find that national filtering policies also seek to shape the narrative by blocking views and perspectives that diverge from government positions on the conflict. While selective exposure to web content is often associated with polarization, we show that social media-in this case Twitter-is used to propagate censored content from the open web, making it more visible to users behind open-web filtering regimes. The evidence shows that government attempts to corral social media users into government-friendly media bubbles does not work, although government filters make it more difficult to access some content. Instead, social media users coalesce into self-defined media spheres aligned around social and political affinities.

\section{AUTHORS}

Helmi Noman is a Research Affiliate of the Berkman Center for Internet \& Society at Harvard University. His research focuses on Internet censorship in the Middle East and North Africa; exploring the impact of information and communication technologies on the Arab information societies; how the use of the Internet defies the social and political structures; and the potential systemic changes cyberspace can bring to real space in the Arab region.

Robert Faris is the Research Director at the Berkman Center for Internet \& Society at Harvard University. His recent research has been focused on developing and applying methods for studying the networked public sphere.

John Kelly is the founder and CEO of Graphika, Inc, and a long-time Research Affiliate of the Berkman Center for Internet \& Society at Harvard University.

\section{ACKNOWLEDGEMENTS}

The authors gratefully acknowledge the support and help of the many people who contributed to this research. Casey Tilton provided editorial feedback on multiple drafts of the report and produced several graphs. Keith McManamen and Psiphon provided data on circumvention tool usage in Yemen and Saudi Arabia. Dan Bateyko provided editing and proofreading assistance. Jonathan Zittrain offered invaluable guidance, support, and advice.

The Twitter data and social network maps used in this paper are courtesy of Graphika, Inc. 


\section{The Yemen War Online: Propagation of Censored Content on Twitter}

\section{Introduction}

In this study we evaluate the use of social media to disseminate information from web sites and online news sources that are normally blocked by government filtering. This work builds upon prior work focused on the evolution of Internet architectural choices and state censorship. Existing technologies used to carry out government-mandated filtering are unable to selectively block specific accounts or web pages when encryption is deployed on online platforms such as Twitter, Facebook, or Wikipedia. ${ }^{1}$ The censors must either block the entire platform or allow everything through. ${ }^{2}$ Users can exploit this feature of encrypted platforms to counter censorship by disseminating banned content through such platforms, as we demonstrated in a recent Egypt case study. ${ }^{3}$

Social links play an important role in the diffusion of information online which often takes the form of information cascades flowing from user to user over social media. ${ }^{4}$ These frequently result in the formation of homogeneous clusters of users that rely on common sources of information that are consistent with their attitudes and worldviews. ${ }^{5}$ The tendency for users to congregate into affinity groups online has fueled some observers' concerns that echo chambers formation will lead to

\footnotetext{
${ }^{1}$ This is most commonly implemented by web sites by making HTTPS the default or only option for users when establishing a connection.

2 Zittrain, Jonathan L., Robert Faris, Helmi Noman, Justin Clark, Casey Tilton, and Ryan Morrison-Westphal. "The Shifting Landscape of Global Internet Censorship." Berkman Klein Center Research Publication No. 2017-4; Harvard Public Law Working Paper No. 17-38. June 1, 2017. available at https://cyber.harvard.edu/publications/2017/06/GlobalInternetCensorship, archived at https://perma.cc/2KLK-DTES.

3 “The Slippery Slope of Internet Censorship in Egypt." Internet Monitor, October 25, 2017. available at https://thenetmonitor.org/bulletins/the-slippery-slope-of-internet-censorship-in-egypt, archived at https://perma.cc/67ZL-MLSM.

${ }^{4}$ See, for example, Io Taxidou and Peter M. Fischer who reconstruct information cascades on Twitter and document the stream of messages over social networks. https: $/ / \mathrm{dl}$.acm.org/ citation.cfm?id $=2580050$ ${ }^{5}$ Del Vicario et al. find a relationship between homogeneity and diffusion of content, and conclude that selective exposure to online content both drives content diffusion and facilitates the formation of homogeneous clusters.

Vicario, Michela Del, Alessandro Bessi, Fabiana Zollo, Fabio Petroni, Antonio Scala, Guido Caldarelli, H. Eugene Stanley, and Walter Quattrociocchi. 2016. “The Spreading of Misinformation Online." Proceedings of the National Academy of Sciences 113 (3): 554-59. available at https://doi.org/10.1073/pnas.1517441113, archived at https://perma.cc/XE9W-VZ8E.
} 


\section{The Yemen War Online}

greater polarization. ${ }^{6}$ Others contest the validity of this argument, presenting evidence that online users are no more subject to echo chambers than consumers of print and broadcast journalism. ${ }^{7}$

In response to censorship, users behind filtering regimes can employ circumvention tools. Accurately measuring the use of circumvention tool usage is challenging; one approach is to survey users. In a 2016 survey of Internet users from 11 jurisdictions in Asia, a quarter of respondents reported having used circumvention (23.5\%), anonymization $(25.0 \%)$, and encryption tools $(26.7 \%)$ to access censored or blocked information online. ${ }^{8}$ A study based on the collection and analysis of more than 100,000 tweets blocked by Twitter in particular regions found that censored content reached a wide audience on Twitter, bypassing censorship measures. The authors inferred from this analysis that users circumvent Internet censorship by using VPN services and anonymizers such as Tor. ${ }^{9}$

Our approach seeks to find if censored content can reach a wide audience on Twitter. Using state Internet censorship around the armed conflict in Yemen as a case study, we examine if censored web content informs users' collective framing of the war despite the fact that warring parties enforce technical censorship of that hostile open web content. The armed conflict in Yemen provides us with a ripe case to explore: the warring parties implement information controls and block websites that provide framing contrary to their own. Also, the conflict has a regional dimension, and as a result, war-aligned censorship exists in multiple political jurisdictions. This gave us the option to examine censorship of open web content in multiple countries involved in the war.

First, we map the conversation on Twitter around the political and armed conflict in Yemen, identity the networks, and examine how users frame the political and armed conflict vis-à-vis military-aligned Internet censorship enforced by warring parties each in its political jurisdiction. As part of the mapping process, we identify the open web content that the political groups use to inform their political outlooks and sentiments. We then investigate if this content is censored by the warring parties. This approach helps us assess if there is any evidence that censored open web content becomes part of the social media ecosystem and contributes to user collective framing of the conflict on their own terms, challenging the state censors who restrict access to that content that informs objectionable framing.

\footnotetext{
${ }^{6}$ See, for example, Sunstein, Cass. \#Republic: Divided Democracy in the Age of Social Media. Princeton University Press. 2017.

${ }^{7}$ Gentzkow, Matthew, and Jesse M. Shapiro. "What drives media slant? Evidence from U.S. daily newspapers." Econometrica 78, no. 1 (2010): 35-71.

${ }^{8}$ Shen, Fei, and Lokman Tsui. 2016. "Public Opinion Toward Internet Freedom in Asia: A Survey of Internet Users from 11 Jurisdictions." Berkman Center Research Publication No. 2016-8. available at https://papers.ssrn.com/abstract=2773802, archived at https://perma.cc/CW38-2992.

${ }^{9}$ Onur, Varol. 2016. "Spatiotemporal Analysis of Censored Content on Twitter." WebSci'16 Proceedings of the 8th ACM Conference on Web Science, May, 372-73. available at https://doi.org/10.1145/2908131.2908208, archived at https://perma.cc/36SV-H23E.
} 


\section{The Yemen War Online}

\section{Research approach}

We apply a mixed methods research protocol to describe activity on Twitter around the conflict in Yemen. We draw on social network mapping techniques to generate a map of users that serves as a guide for qualitative content analysis. The Twitter map is created using the follows relationships among the relevant users, and then clustering algorithms are applied to reveal group affiliations that are based on the commonality of outward attention among the users.

The mapping process starts with a set of hand curated seed accounts. This set is augmented by adding all of the followers of these seed accounts, and the followers of the followers. A k-core analytical process is used to locate the most highly connection accounts and remove those that are less highly connected. Accounts that are inactive are also removed. The resulting map includes 11,894 accounts. The network map and structures reflect the individual decisions of Twitter users to follow other users, and the clustering reveals distinct groups. Qualitative human judgment is then used to interpret and describe the resulting clusters of users. ${ }^{10}$

Each of the nodes on the maps is an individual account. The size of each node reflects the number of followers in the network, and the colors denote the different clusters of users based on the accounts that they follow.

We identified networks of three political factions involved in the conflict in Yemen. ${ }^{11}$ We then extracted from the map the lists of URLs of open web media sources used by each network. We tested access to each set of URLs from Yemen, Saudi Arabia, Iran, and the UAE to determine which government censors object to what content. We tested the URLs in Yemen because it is the stage of the conflict where the national ISP is controlled by the Houthis; Saudi Arabia because it is engaged in the war by leading an Arab military campaign to reinstate the government of the internationally recognized president of Yemen; Iran because the government of president Hadi and the Arab coalition have accused Iran of supporting the Houthis militarily; and the UAE because it plays a prominent military role in the war in Yemen as a member of the Arab military coalition. ${ }^{12}$

${ }^{10}$ For a full description of the methods applied, see: Noman, Helmi, Robert Faris, and John Kelly. 2015. "Openness and Restraint: Structure, Discourse, and Contention in Saudi Twitter." Berkman Center Research Publication No. 2015-16 available at https://papers.ssrn.com/abstract $=2700944$, archived at https://perma.cc/WMV3-GBSH.

11 Other networks also surfaced in the map but they were not included in this paper because they do not add value or fall within the scope of the research. For example, a network of South Yemen Separatists was excluded because it resembles the Hadi Government Supporters on the issue of open web content consumption.

${ }^{12}$ Sam, Wilkin. 2015. "UAE Troops Dig in for a Long War in Yemen.” Reuters, December 2, 2015. available at https://www.reuters.com/article/us-yemen-security-emirates/uae-troops-dig-in-for-a-long-war-in-yemenidUSKBN0TL14T20151202, archived at https://perma.cc/5WNP-KXBA. 


\section{The Yemen War Online}

We started the test runs in April 2016 and continued to update the test results until November 2017. The tests documented the scope and depth of Internet filtering in the four countries and captured an increase in the filtering scope and depth as the political and armed conflicts intensified.

We ran the tests remotely using open proxies and VPNs on Yemen's ISP YemenNet, Saudi Arabia's Saudi Telecom (STC), Iran's Parsnet, and UAE's Etisalat and du. Each ISP serves a blockpage for objectionable content, which makes it easy for us to detect blocking. Yemen's ISP YemenNet consistently serves a "404 Page Not Found" error message for political websites. In October 2015, the Citizen Lab, an interdisciplinary laboratory based at the Munk School of Global Affairs, University of Toronto, concluded in a technical investigation that this was disguised blocking. ${ }^{13}$

Moreover, as part of the mapping process, we calculated the number of accounts which cited each URL. The citation count for a URL is the number of Twitter accounts that shared at least one URL to that website during the mapping window, which was 7 days. This helps us find out how many blocked URLs have indeed been shared in a certain period. ${ }^{14}$

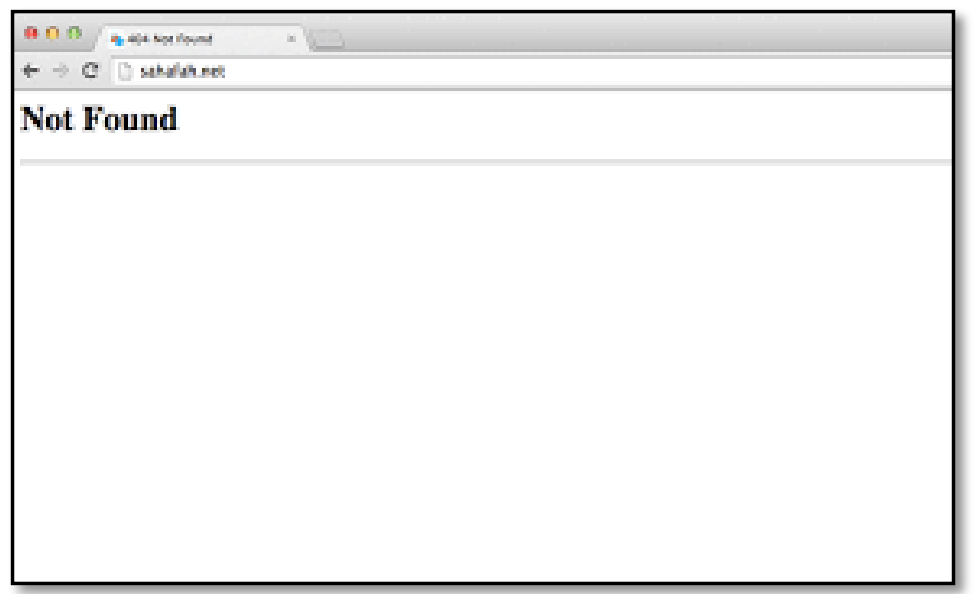

Figure 1: Yemen (YemenNet) blockpage ${ }^{13}$

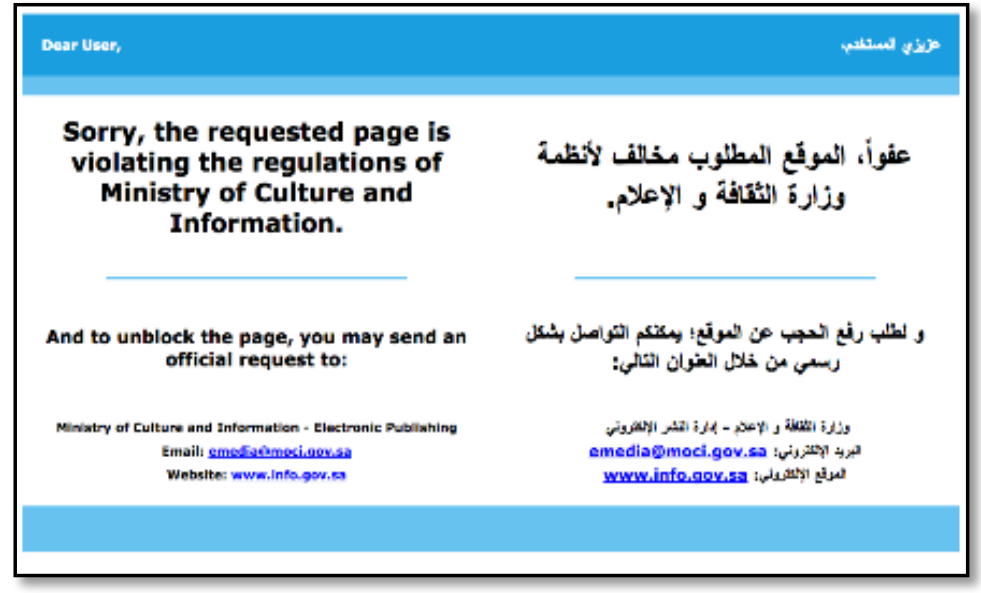

Figure 2: Kingdom of Saudi Arabia (STC) blockpage

\footnotetext{
${ }^{13}$ Irene, Poetranto. 2015. "Canadian Company Censors Internet in War Zone for Yemeni Rebel Group Targeted by UN Sanctions." The Citizen Lab. October 21, 2015. available at https://citizenlab.ca/2015/10/netsweeper-censors-internet-yemen, arcbived at https://perma.cc/2GHF$\underline{\text { SWY9. }}$

${ }_{14}$ We excluded websites from the Iran website count which are hosted on permanently blocked platforms, such as blogspot.com, and websites blocked prior to the war in Yemen, such as Human Right Watch (hrw.org).
} 


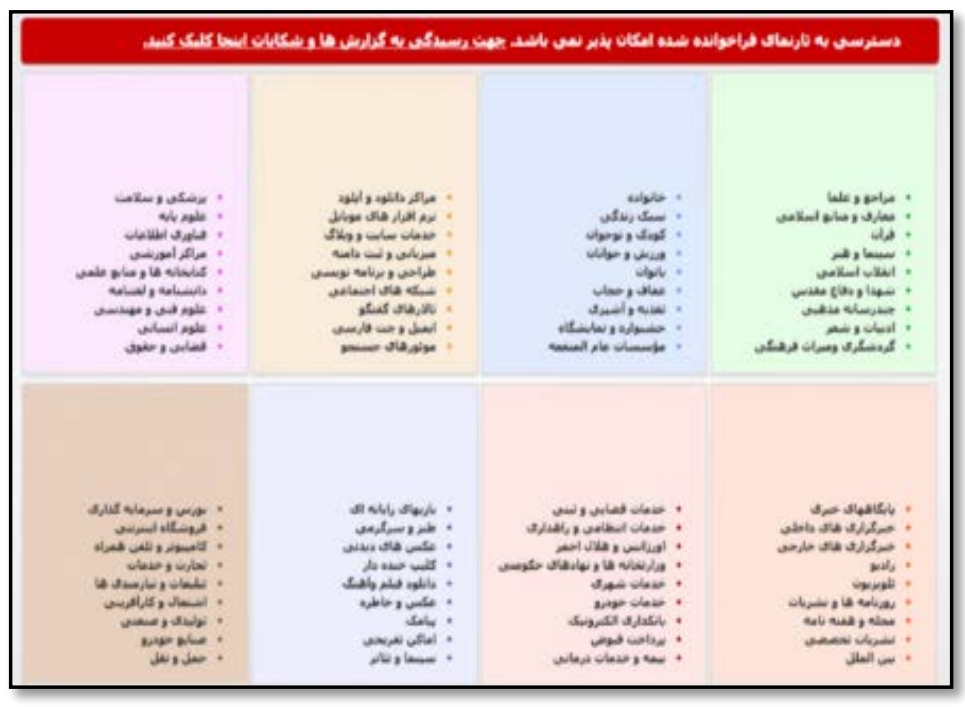

Figure 3: Iran (Parsne) blockpage

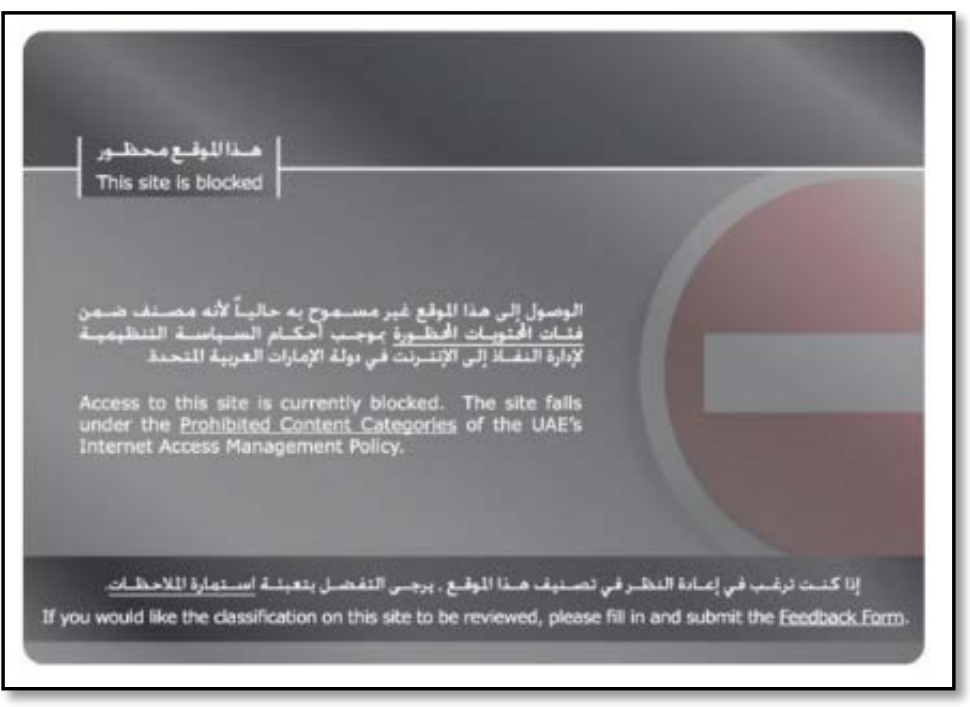

Figure 4: United Arab Emirates (Etisalat) blockpage

\section{About the armed conflict in Yemen}

Yemen has been fractured by a devastating civil war between forces loyal to the government of Abd Rabu Mansour Hadi and an alliance of Houthi fighters and forces loyal to former president Ali Abdullah Saleh. Hadi, the internationally recognized president of Yemen, is backed by a Saudi-led Arab military coalition. The Houthis, a religious and political movement that emerged from northern Yemen, are ideologically aligned with Iran and reportedly receive military support from Iran, an allegation Iran denies. ${ }^{15}$ Saleh allied himself with the Houthis to take revenge on political actors who contributed to removing him from power in 2012. The Houthi-Saleh alliance was predated by animosity and armed confrontations between Houthi fighters and Saleh forces during his reign as president. ${ }^{16}$ The alliance broke in December 2017 when Saleh declared his intention to reset his relations with Saudi Arabia against the Houthis. Two days after severing the alliance, Saleh was killed amid the resulting armed clashes between his forces and the Houthis. ${ }^{17}$

${ }^{15}$ BBC News. 2015. "Yemen Crisis: Kerry Warns Iran over Houthi Rebel 'Support,” April 9, 2015, sec. Middle East. available at http://www.bbc.com/news/world-middle-east-32229316, archived at https://perma.cc/B2H7-SL25.

16 United Nations Security Council, 2016. "Letter dated 20 February 2015 from the Panel of Experts on Yemen established pursuant to Security Council resolution 2140 (2014) addressed to the President of the Security Council." 20 February 2016. available at, http://www.un.org/ga/search/view_doc.asp?symbol=S/2015/125, archived at https://perma.cc/3AGUTP2Y.

${ }^{17}$ Al Jazeera. 2017. "Yemen: Ex-President Ali Abdullah Saleh Killed," December 10, 2017. available at https://www.aljazeera.com/news/2017/12/houthi-media-ali-abdullah-saleh-killed-sanaa171204123328290.html, archived at https://perma.cc/9UG3-2XWE. 


\section{The Yemen War Online}

The Houthis took over the capital Sana'a militarily in September 2014, and in February 2015 they dissolved the parliament and appointed a revolutionary committee as a de facto government. Hadi fled house arrest in Sana'a and set up the southern city of Aden as a temporary capital. ${ }^{18}$ Hadi later fled to Saudi Arabia after Houthi forces advanced closer to Aden. In March 2015, Saudi Arabia launched a military campaign labelled Decisive Storm as part of a US-backed military coalition consisting of nine mostly Sunni Arab states to intervene in the conflict in support of the Hadi government. ${ }^{19}$ The United Nations Security Council imposed a global travel ban and asset freeze on two Houthi leaders and Saleh "for threatening the peace and stability of the country and obstructing the political process." ${ }^{20} \mathrm{UN}$-appointed special envoys to Yemen have been facilitating rounds of peace talks between the Yemeni sides since June 2015, but the talks have made no progress. ${ }^{21}$

18 BBC News. 2017. "Yemen Country Profile," December 4, 2017, sec. Middle East. available at http://www.bbc.com/news/world-middle-east-14704852, arcbived at https://perma.cc/YDN4-FSXT. ${ }_{19}$ Reuters. 2015. "Factbox: Saudi-Led Coalition against Yemen's Houthis," April 10, 2015. available at https://www.reuters.com/article/us-yemen-security-coalition-factbox/factbox-saudi-led-coalition-againstyemens-houthis-idUSKBN0N11F220150410, archived at https://perma.cc/ES5E-3NTJ.

${ }^{20}$ Reuters. 2014. “U.N. Sanctions Yemen's Ex-President Saleh, Two Rebel Leaders,” November 7, 2014. available at

https://www.reuters.com/article/us-yemen-un-sanctions/u-n-sanctions-yemens-ex-president-saleh-tworebel-leaders-idUSKBN0IR2EA20141107, archived at https://perma.cc/6YG3-9PP5.

${ }^{21}$ Section, United Nations News Service. n.d. "Yemen." UN News Centre. available at http://www.un.org/apps/news/infocusRel.asp?infocusID=154\&Body=Yemen\&Body1, archived at https://perma.cc/WW92-J36N. 


\section{How the Yemen Twitter map is shaped by the war}

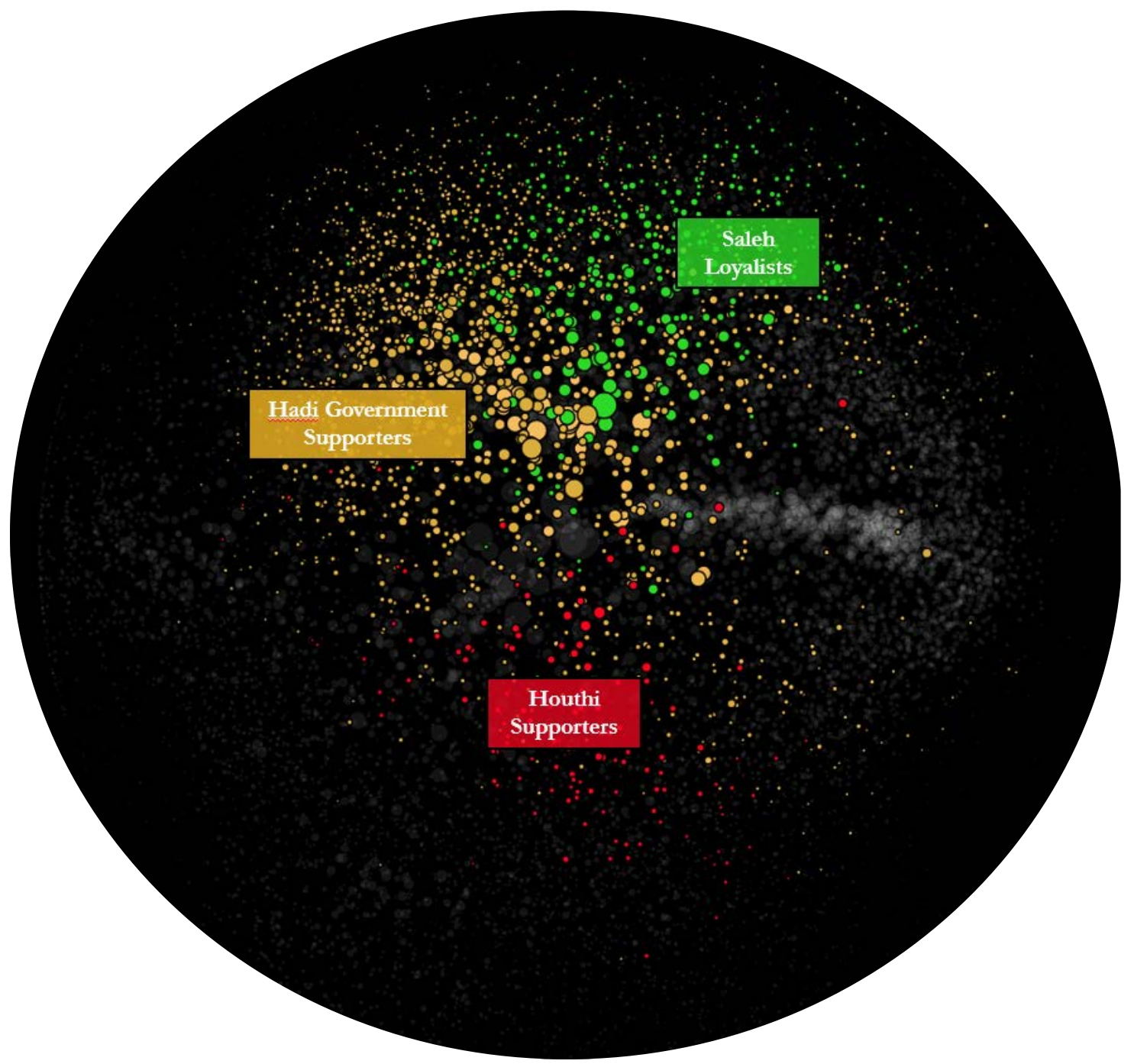

Figure 5: Yemen Political Twitter Map

The map includes three largely homogeneous networks segregated on political lines and the stance on the war. The networks are Hadi Government Supporters, Houthi Supporters, and Saleh Loyalists. The map is profoundly shaped by the political and armed conflicts. Polarized narrative and war-torn culture prevails throughout the networks. Users in each network frame the conflict on their terms and express their sentiments on political developments, daily war activities, the Saudi-led military intervention, and UN-sponsored attempts to broker a political resolution to end the conflict. 


\section{Overview of the networks}

\section{Hadi Government Supporters}

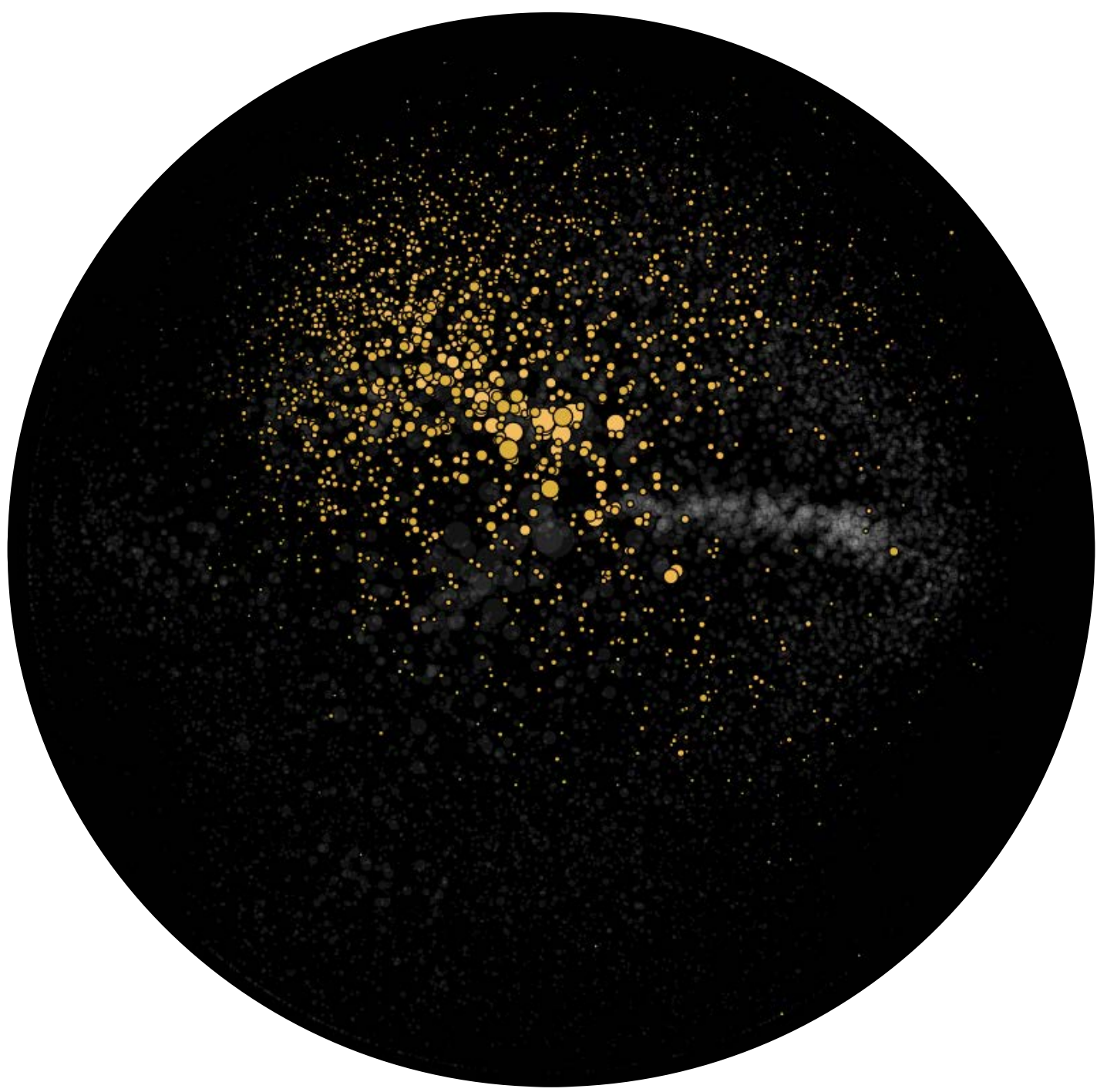

Figure 6: Hadi Government Supporters

Users in this network are strongly critical of the Houthis and Saleh. They support the military efforts carried out by the government of president Hadi and the Saudi-led coalition and consider the Houthi takeover over of the country a military coup. They argue that the coalition's military intervention in Yemen is necessary to restore the government of president Hadi and to fight "Iranbacked" Houthi fighters. The users disseminate content about alleged Houthi and Saleh's forces' atrocities and human rights violations. A noticeable change in tone occured after the killing of 
former president Saleh by Houthi fighters in December 2017. Since then, more users have started to honor his attempt to break his alliance with the Houthis.

Voices which are critical of the Hadi government or the Arab coalition, yet are against the Houthis, appear in this network. Supporters of the government of president Hadi use websites that report on military operations against the Houthis and Saleh and that are critical of their military actions and human rights records.

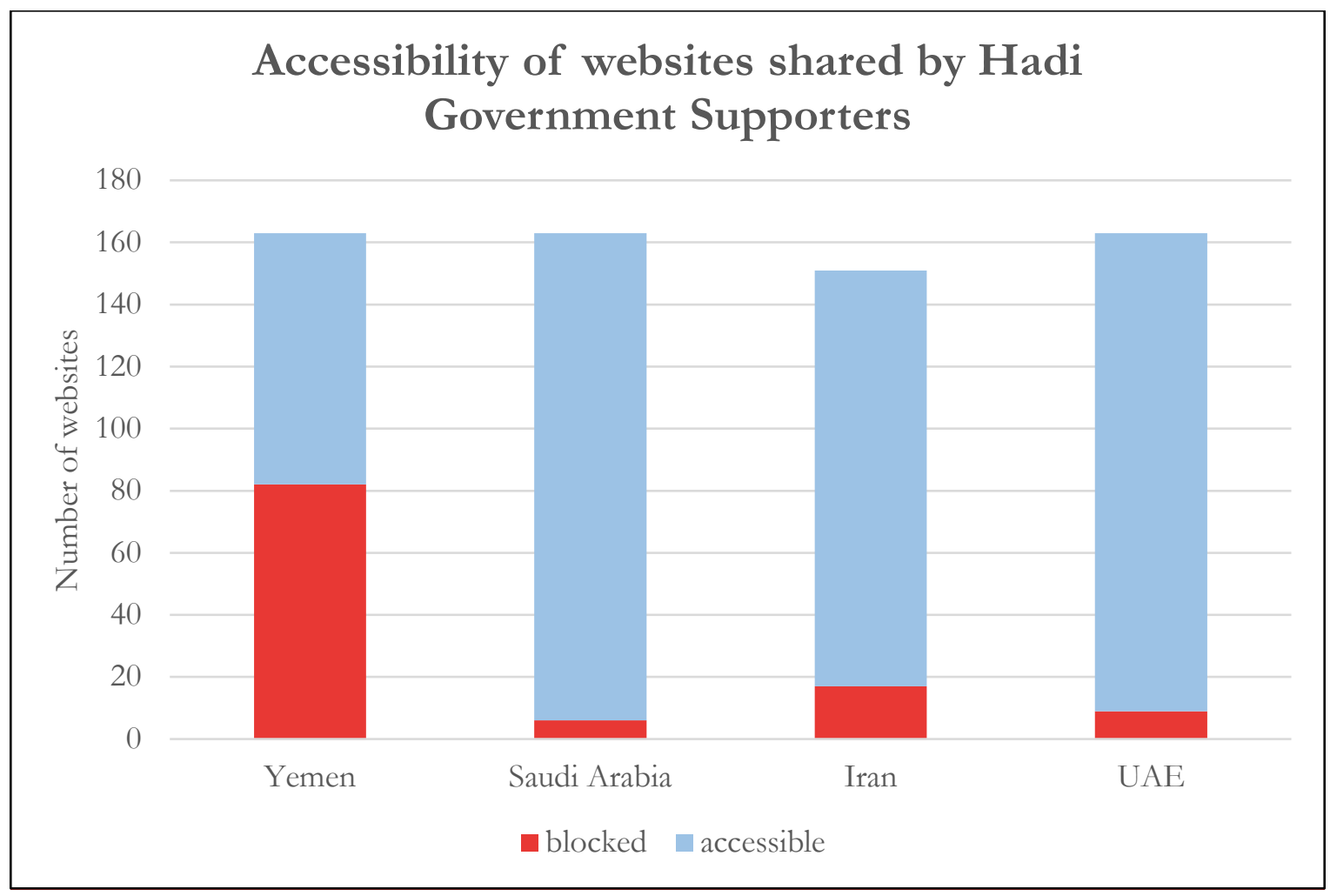

Figure 7

\begin{tabular}{|c|c|c|c|c|c|c|c|}
\hline \multirow[b]{2}{*}{ Website } & \multicolumn{3}{|c|}{ Number of network citations } & \multirow[b]{2}{*}{$\begin{array}{c}\text { Accessibility in } \\
\text { Yemen }\end{array}$} & \multirow[b]{2}{*}{$\begin{array}{c}\text { Accessibility in } \\
\text { Saudi Arabia }\end{array}$} & \multirow[b]{2}{*}{$\begin{array}{c}\text { Accessibility in } \\
\text { Iran }\end{array}$} & \multirow[b]{2}{*}{$\begin{array}{c}\text { Accessibility in } \\
\text { UAE }\end{array}$} \\
\hline & $\begin{array}{l}\text { Hadi Govt. } \\
\text { Supporters }\end{array}$ & $\begin{array}{c}\text { Houthi } \\
\text { Supporters }\end{array}$ & $\begin{array}{c}\text { Saleh } \\
\text { Loyalists }\end{array}$ & & & & \\
\hline marebpress.net & 159 & 0 & 0 & blocked & accessible & blocked & accessible \\
\hline sahafah.net & 78 & 3 & 26 & blocked & accessible & accessible & accessible \\
\hline almasdaronline.com & 71 & 0 & 1 & blocked & accessible & accessible & accessible \\
\hline adenalghad.net & 55 & 0 & 0 & blocked & accessible & accessible & accessible \\
\hline vemen-press.com & 43 & 0 & 0 & blocked & accessible & blocked & accessible \\
\hline
\end{tabular}

Table 1: Top five news websites cited by Hadi Government Supporters during the seven day mapping window 


\section{Houthi Supporters}

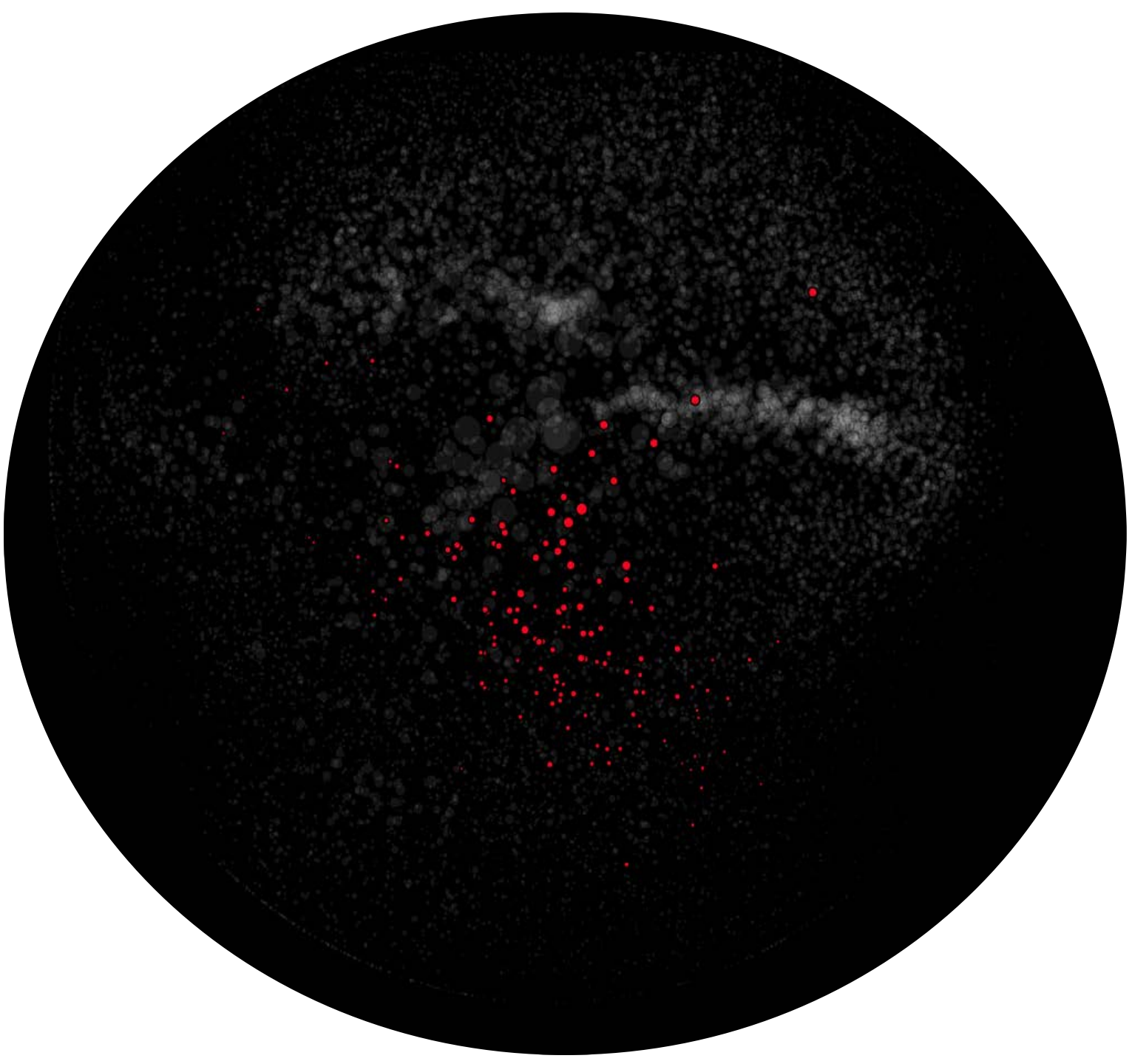

Figure 8: Houthi supporters

The network is populated by users aligned with the Houthis. They lambaste the military campaigns against Houthi fighters and forces loyal to Saleh and consider the Houthi takeover of the country a popular revolution. They argue that president Hadi lost his legitimacy after he invited foreign military operations into Yemen. The users post graphic footage showing what they describe as atrocities caused by Saudi military operations in Yemen. After the killing of Saleh, users in this network celebrated his slaying and launched information campaigns against those who remained loyal to him. 
Houthi supporters use websites which usually refer to their takeover of the capital Sana'a as a popular revolution, report on their actions in Yemen in a favorable tone, and extensively report on their military operations against forces loyal to the government of Hadi and Saudi Arabia.

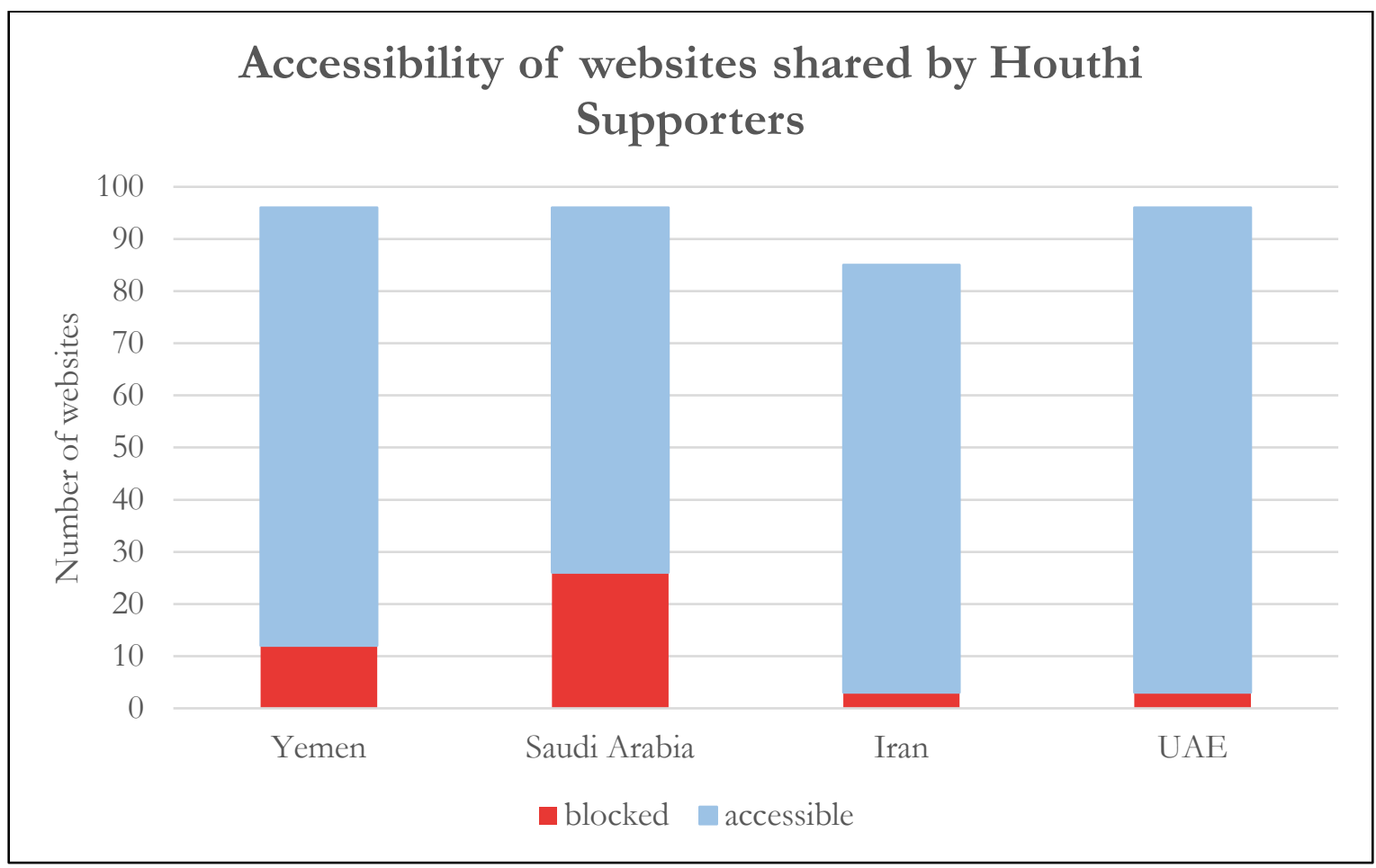

Figure 9

\begin{tabular}{|c|c|c|c|c|c|c|c|}
\hline \multirow[b]{2}{*}{ Website } & \multicolumn{3}{|c|}{ Number of network citations } & \multirow[b]{2}{*}{$\begin{array}{c}\text { Accessibility in } \\
\text { Yemen }\end{array}$} & \multirow[b]{2}{*}{$\begin{array}{c}\text { Accessibility in } \\
\text { Saudi Arabia }\end{array}$} & \multirow[b]{2}{*}{$\begin{array}{c}\text { Accessibility in } \\
\text { Iran }\end{array}$} & \multirow[b]{2}{*}{$\begin{array}{c}\text { Accessibility in } \\
\text { UAE }\end{array}$} \\
\hline & $\begin{array}{c}\text { Houthi } \\
\text { Supporters }\end{array}$ & $\begin{array}{l}\text { Hadi Govt. } \\
\text { Supporters }\end{array}$ & $\begin{array}{c}\text { Saleh } \\
\text { Loyalists }\end{array}$ & & & & \\
\hline www.alalam.ir & 29 & 0 & 0 & accessible & blocked & accessible & blocked \\
\hline www.almanar.com.lb & 18 & 0 & 0 & accessible & blocked & accessible & blocked \\
\hline www.khabaragency.net & 11 & 0 & 61 & accessible & blocked & accessible & accessible \\
\hline thelinkyemen.net & 11 & 0 & 0 & accessible & blocked & accessible & accessible \\
\hline www.almasirah.tv & 7 & 0 & 3 & accessible & blocked & accessible & accessible \\
\hline
\end{tabular}

Table 2: Top five news websites cited by Houthi Supporters during the seven day mapping window 


\section{Saleh Loyalists}

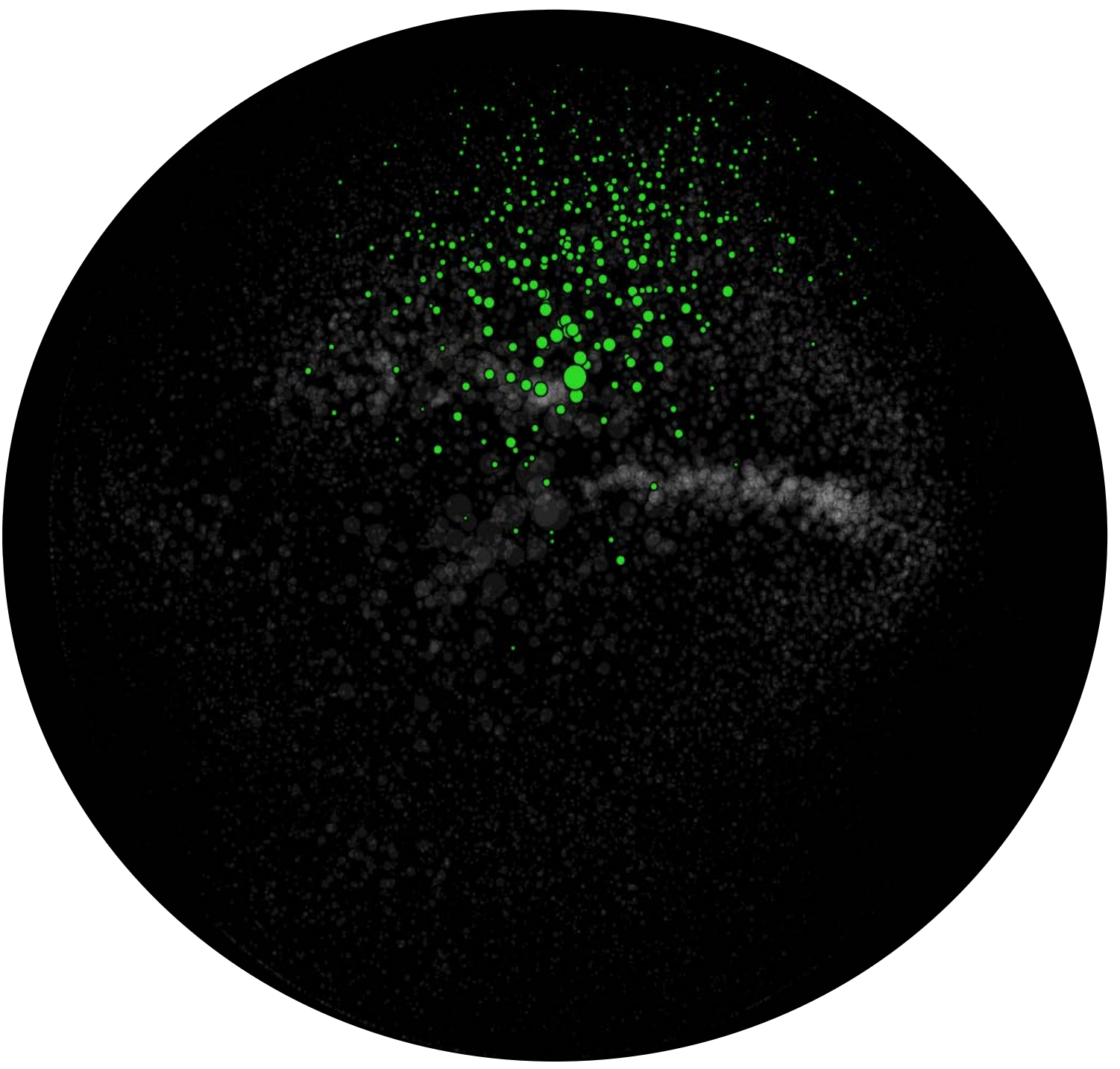

Figure 10: Saleh Loyalists

The network ${ }^{22}$ is comprised of individuals loyal to Saleh. They mourn the end of his presidency, support the military operations against the troops loyal to Hadi, and condemn the Saudi-led military operations. They hold president Hadi accountable for the collapse of the political system in Yemen.

\footnotetext{
22 The Houthi Supporters and Saleh Loyalists networks have appeared apart on the map though the mapping was conducted when their political alliance was still in effect. The animosity and armed confrontations which occurred between the Houthis and Saleh during his reign is probably why the two allies remained separate online. The fact that the alliance bloodily ended with the killing of Saleh by Houthi forces gives credence to this explanation.
} 
Voices in this network started to disavow their alliance with the Houthis after the killing of Saleh by the Houthis. Saleh loyalists use websites which disseminate his speeches and point of view on the conflict and military developments and which are critical of Hadi and the Saudi military operations.

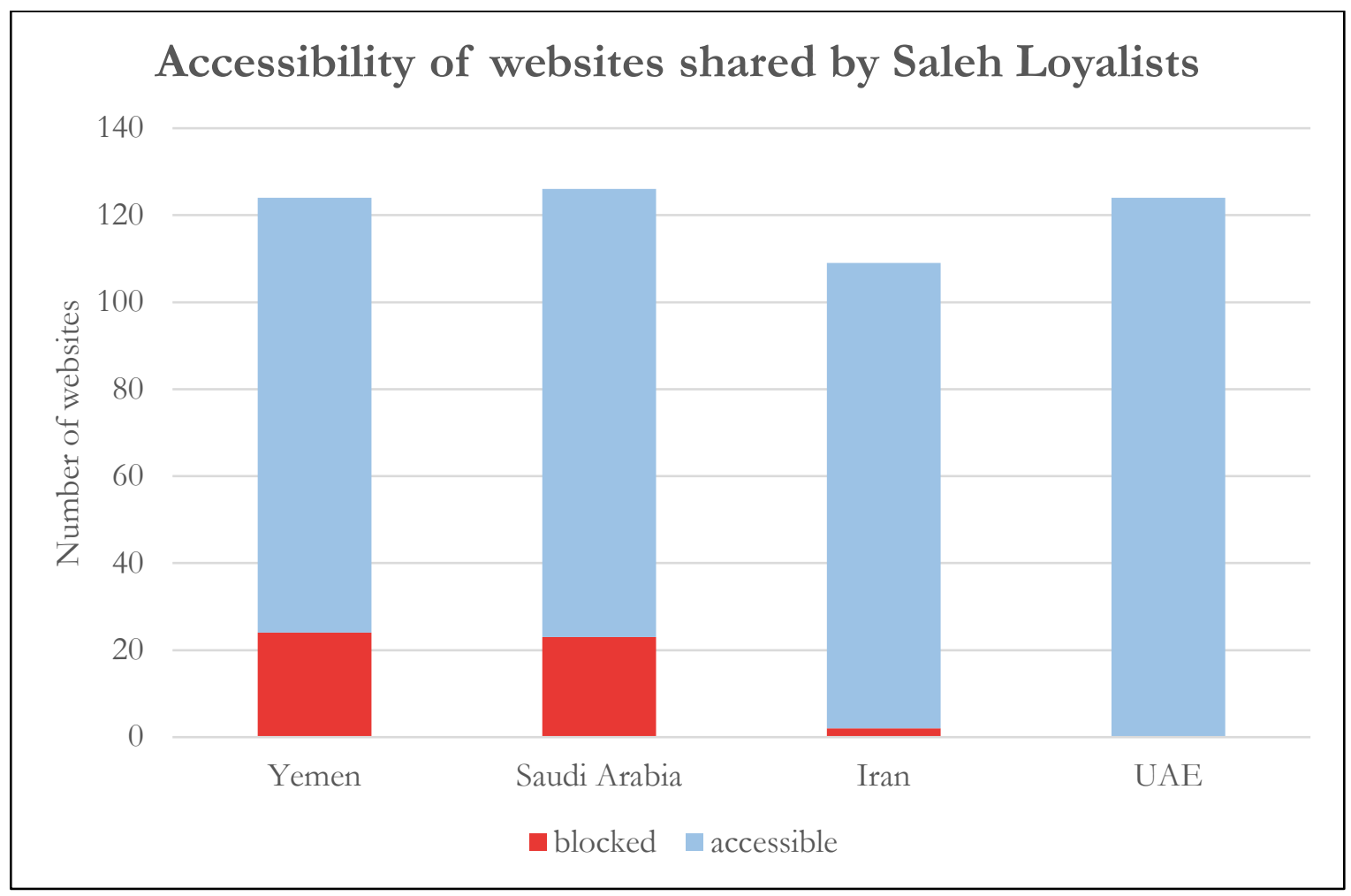

Figure 11

\begin{tabular}{|c|c|c|c|c|c|c|c|}
\hline \multirow[b]{2}{*}{ Website } & \multicolumn{3}{|c|}{ Number of network citations } & \multirow[b]{2}{*}{$\begin{array}{c}\text { Accessibility in } \\
\text { Yemen }\end{array}$} & \multirow{2}{*}{$\begin{array}{c}\text { Accessibility in } \\
\text { Saudi Arabia }\end{array}$} & \multirow[b]{2}{*}{$\begin{array}{c}\text { Accessibility in } \\
\text { Iran }\end{array}$} & \multirow[b]{2}{*}{$\begin{array}{c}\text { Accessibility in } \\
\text { UAE }\end{array}$} \\
\hline & $\begin{array}{c}\text { Saleh } \\
\text { Loyalists }\end{array}$ & $\begin{array}{l}\text { Hadi Govt. } \\
\text { Supporters }\end{array}$ & $\begin{array}{c}\text { Houthi } \\
\text { Supporters }\end{array}$ & & & & \\
\hline www.khabaragency.net & 61 & 0 & 11 & accessible & blocked & accessible & accessible \\
\hline wrww.almontasaf.net & 19 & 0 & 4 & accessible & blocked & accessible & accessible \\
\hline www.almotamar.net & 19 & 0 & 0 & accessible & blocked & accessible & accessible \\
\hline www.yementodaytv.net & 13 & 0 & 1 & accessible & blocked & accessible & accessible \\
\hline www.albidapress.net & 13 & 0 & 0 & accessible & blocked & accessible & accessible \\
\hline
\end{tabular}

Table 3: Top five news websites cited by Saleh Loyalists during the seven day mapping window 


\section{Circumventing Internet filtering}

Data from circumvention tool service Psiphon confirm that a significant number of users in Yemen and Saudi Arabia, the two countries directly involved in the war, bypass local filtering regimes by employing circumvention tools. We can infer from this that users behind filtering regimes can access censored open web content and share blocked content on social media platforms including Twitter. Twitter and other platforms that have implemented HTTPS serve as recommendation systems for both blocked and unblocked content. Users who encounter blocked URLs on Twitter can use circumvention tools to bypass the filtering. Moreover, the sharing of blocked content on social media platforms serves as an incentive to adopt circumvention tools.

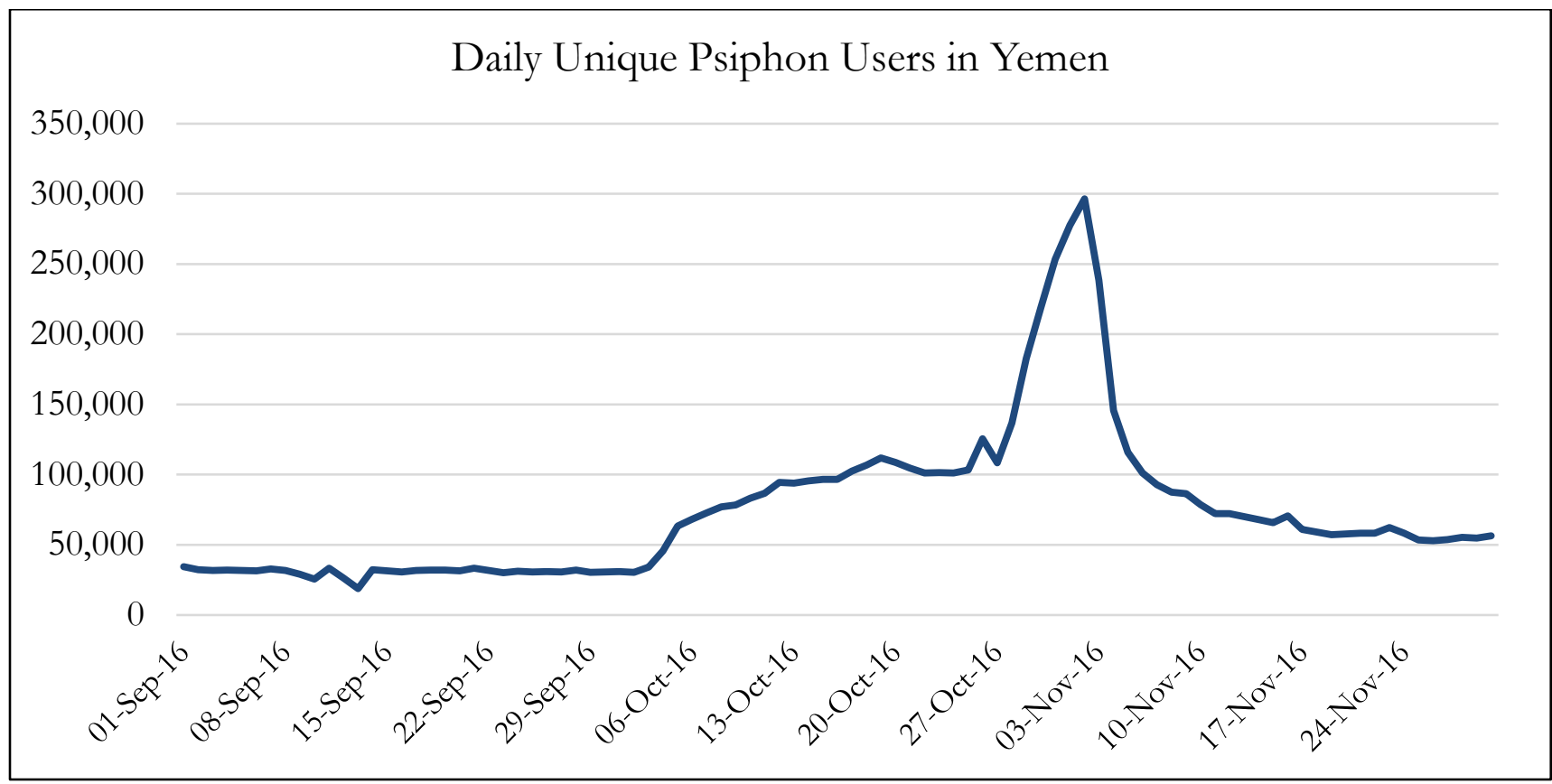

Figure 12 
In Yemen and Saudi Arabia, spikes in circumvention tool usage occur during periods of increased Internet filtering. For example, there was a sharp increase in the number of daily users of Psiphon in December 2017, when the Houthi-controlled YemenNet temporarily blocked social media platforms and messaging apps, including Twitter, Facebook, Telegram, and WhatsApp (Figure 12). ${ }^{23}$ Similarly, there was a spike in the number of daily Psiphon users in Saudi Arabia in May 2016 when the government blocked Facebook Messenger and the video call and messaging app imo (Figure 13). ${ }^{24}$

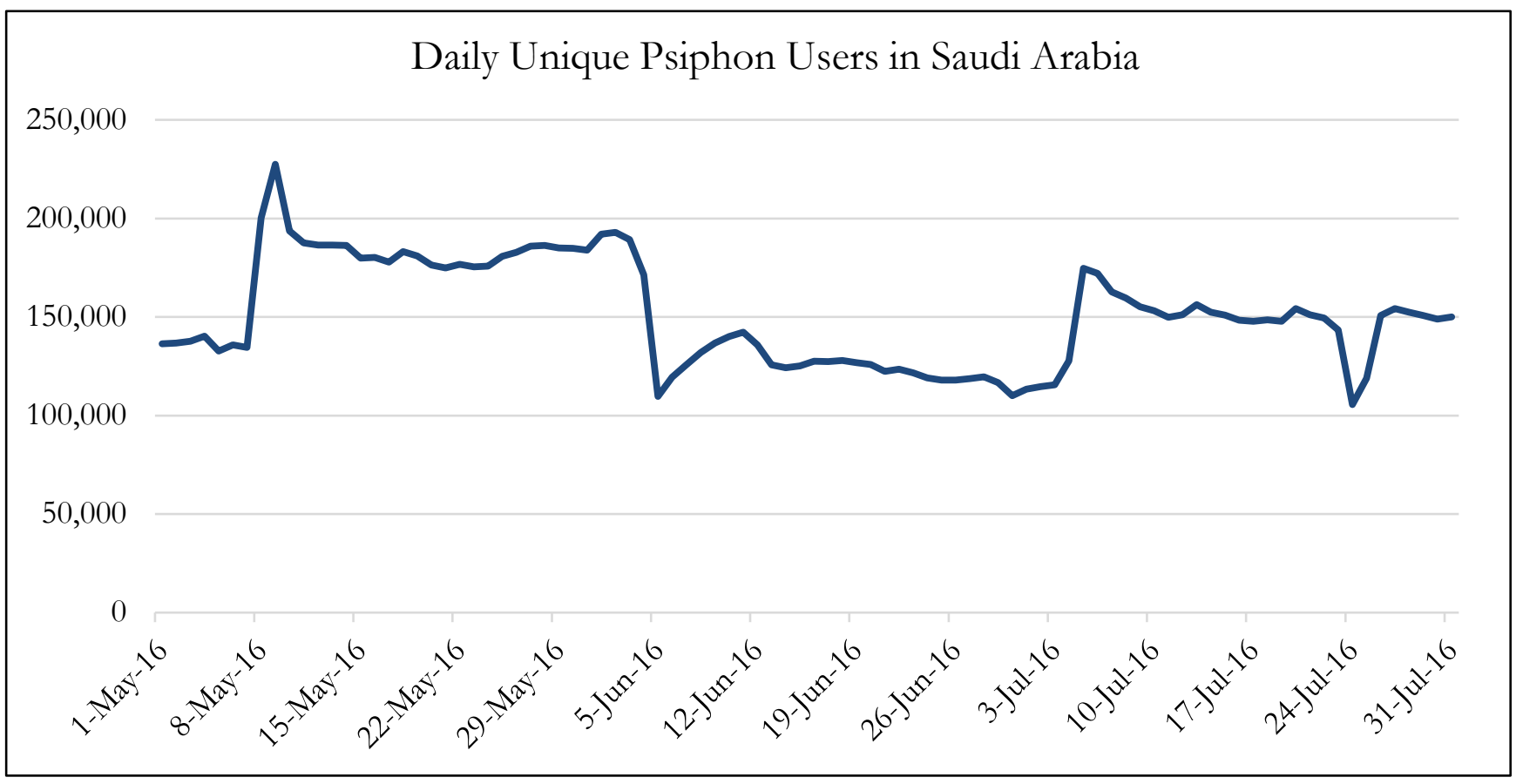

Figure 13

\section{Discussion and Conclusion}

The three distinct networks we identified and analyzed on Twitter reflect the political affinities of the groups vying for control of the narrative on the war. Each focuses attention on open web media sources that frames the narrative around the conflict in a manner that is favorable to their side. The most cited URLs in each of the networks constitute a distinct set of websites that are different from the other networks with content that generally matches the overall political outlook and positions on the war of the three factions.

23 "Internet Shutdown in Yemen: Recurring Disruptions Threaten Civilian Safety, Human Rights, and Press Freedom." 2017. SMEX. December 8, 2017. available at https://smex.org/internet-shutdown-in-yemenrecurring-disruptions-threaten-civilian-safety-human-rights-and-press-freedom/, archived at https://perma.cc/Q3Y9-DRPW.

${ }^{24}$ Rashid, Hassan. "Messenger Call Outage Leaves Users Baffled." Arab News, May 11, 2016. available at http://www.arabnews.com/news/messenger-call-outage-leaves-users-baffled, archived at https://perma.cc/A5L4-UA9N. 
The Twitter users found in the three principal networks are aware of the censorship measures conducted by those who control the telecommunications infrastructure and that frequently target the web sources and narratives of rival parties. The response of Twitter users, who operate outside of the reach of technical Internet filters, is to act as content curators by highlighting articles and web resources that are being censored. These updates on political and military ongoings are thereby visible on Twitter to users that reside behind Internet filtering regimes. These updates include graphic footage of civilian casualties and atrocities each side attributes to their adversaries. Such content is either readily viewable on Twitter itself as text, graphics, or video clips or available on blocked websites that users can reach by following the shared links. In effect, the platform becomes a collaborative ecosystem where censored content from the open web is highlighted and propagated.

We are not able to accurately determine the physical location of the Twitter users that are a part of this conversations. Some reside in the countries where the media sources that include unfavorable coverage of government actions are blocked. Others live in regions that are not subject to the same filtering regime. We have evidence that users residing in the two countries directly engaged in the war integrate circumvention tools in their surfing behavior.

We are able to accurately determine which websites that are most popular among the different political factions are blocked in different countries in the region. In each case, test results show that a high percentage of each network's preferred set of URLs is blocked in the rival political jurisdiction. The Houthi-controlled ISP in Yemen blocks a substantial portion of the websites that inform the narratives favorable to the Hadi Government Supporters network. Similarly, Saudi Arabia blocks a large number of the websites informing the discourse in the Houthi Supporters and Saleh Loyalists networks.

Using the number of blocked websites and number of accounts that cited blocked URLs as proxies, we infer that censored content from the open web is assimilated and propagated in each network. The social links and homogeneity of these networks are catalysts for the diffusion of information. Despite the attempts to wall off users from certain content, those who participate in the networks are exposed to censored content regardless of their political jurisdiction and the filtering regime therein. 